\title{
THE AMYLOLYTIC AND PHOSPHATASE ACTIVITY OF LIVER TISSUE IN VON GIERKE'S DISEASE ${ }^{1}$
}

\author{
By S. J. THANNHAUSER, S. Z. SORKIN,2 AND N. F. BONCODDO
}

(From the Laboratories of the Tufts Medical School at the Boston Dispensary, Boston)

(Received for publication March 27, 1940)

The pathogenesis of von Gierke's disease is not known. Shortly after the disease was described (1), the increased glycogen storage was attributed to a disturbance of the glycogen splitting ferments (2). This stimulated studies of the amylolytic activity of the diseased tissues, since amylase was the only glycogen splitting enzyme known at that time. Several investigators $(3,4,5)$ found amylase present in the von Gierke tissue. Our determinations corroborate these findings as may be seen in Table I.

TABLE I

Amylolytic activity of liver tissue

\begin{tabular}{|c|c|}
\hline Source of tissue & 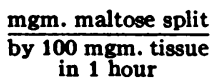 \\
\hline $\begin{array}{l}\text { von Gierke's disease, Case I... } \\
\text { von Gierke's disease, Case II } \\
\text { von Gierke's disease, Case III } \\
\text { Normal liver (Child). . . . . . } \\
\text { Normal liver (Adult) } . \ldots \ldots \\
\text { Fatty liver (Alcoholic cirrhosi } \\
\text { Liver from patient with elev } \\
\text { blood-amylase activity..... }\end{array}$ & $\begin{array}{ll}\ldots \ldots & 2.55 \\
\ldots \ldots & 0.70 \\
\ldots \ldots & 1.70 \\
\ldots \ldots & 1.75 \\
\ldots \ldots & 1.45 \\
\text { is) } \ldots & 1.02 \\
\text { vated } & \\
\ldots \ldots & 3.10\end{array}$ \\
\hline
\end{tabular}

Recently Cori (6) has shown that the conversion of glycogen to glucose in the liver results from the combined action of a phosphorylase which catalyzes the hydrolysis of the glycogen to glucose-1-phosphoric acid ester and a phosphatase which splits the ester to glucose and inorganic phosphate. Ostern, Herbert, and Holmes (7) report similar findings and demonstrate in addition that the amylase could not account for more than 15 per cent of the glycogenolysis in their experiments. In view of this recently demonstrated mechanism for the conversion of glycogen to glucose in the liver, and since the amylolytic activity of the liver tissue is probably normal in von Gierke's disease, the possibility of a disturbance in the phosphorylase-phosphatase system was considered.

\footnotetext{
1 Work aided by a grant from the Rockefeller Foundation, the Bingham Associates Fund, and the Charlton Fund.

2 Emanuel Libman Fellow.
}

Liver tissue from three fatal cases of von Gierke's disease was examined for its phosphatase and amylolytic activity. For comparison parallel experiments were carried out with tissue obtained from normal livers and from livers showing marked fatty change. The latter were chosen for comparative studies because the abnormally high fat content of the von Gierke liver made it necessary to consider the possibility of the fat interfering with the normal phosphorylase-phosphatase conversion of glycogen. The fatty livers contained 38.5, 25, and 34 per cent fat (determined as fatty acids in dried tissue). The fat content of the von Gierke livers was 52.34, 34.2, and 22.6 per cent; the corresponding glycogen content was 27, 12.7, and 36.6 per cent (of the dried tissue weight). Total wet weights of these latter livers were 1216 grams, 1063 grams, and 250 grams, respectively. Detailed data concerning the partition of the liver tissue lipid content will be published subsequently.

The enzyme preparations consisted of dried powdered liver obtained by freezing ( 8 ). The final product was washed with small portions of acetone and dried again in a desiccator. The alkaline phosphatase activity was determined by a modification of the Bodansky method (9), using 20 milligrams of dried liver powder and a 24hour period for hydrolysis. The method was also employed in determining the acid-phosphatase activity except that an $\mathrm{N}$ acetate buffer ( $\mathrm{pH}$ 5.0) was substituted for the alkaline buffer. The phosphatase values obtained are shown in Table II.

Aqueous extracts of the powdered tissue were used in determining the amylolytic activity. The latter was measured with a method described elsewhere $(10)$. Since the method utilizes starch as a substrate and a phosphate buffer it may not measure the activity of the amylase alone. Even though adenylic acid, considered to be essential for the phosphorylation reaction (Cori), was not added, the reducing substances measured may have included glucose. However, amylolytic ac- 
TABLE II

\section{Phosphatase activity* of liver tissue}

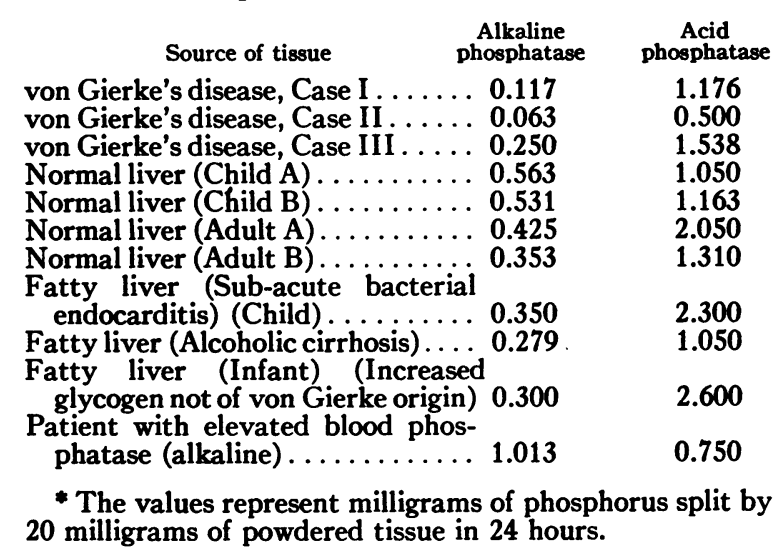

tivity was demonstrated by qualitative iodine tests during the course of the amylase hydrolysis. Color changes indicative of the formation of dextrins were obtained.

As may be seen in Table II, the alkaline phosphatase activity of the von Gierke liver tissue was definitely decreased as compared to that of the normal livers of children. The range of alkaline phosphatase activity in fatty livers of both children and adults was somewhat lower than that in the normal liver tissue of corresponding groups. In tissue from a fatty liver which contained a relatively large amount of glycogen (8 per cent), but which was not from a genuine case of von Gierke's disease, the alkaline phosphatase activity was also decreased as compared to that in the normal liver tissue of children.

The acid phosphatase activity in each liver except one (liver from a patient who had markedly elevated alkaline blood phosphatase activity) was greater than the alkaline phosphatase activity. However, no definite ratio was found, nor was any alteration of the acid phosphatase noted in von Gierke's disease.

The identity of the glucophosphatase with the alkaline glycerophosphatase has not been definitely established. Hexosephosphate is hydrolyzed by bone phosphatase (11). Liver phosphatase splits glycerophosphate, glucose- 1 and glucose6 phosphate at about the same rate (6). It is still uncertain if, in addition, a phosphatase exists that specifically dephosphorylates the Cori ester (7). Decisive information concerning the nature of the phosphatases is still lacking.
A disturbance of the phosphatase which would leave the glucose-phosphates unsplit and therefore available for glycogen resynthesis could result in an increased storage of the polysaccharide. A decrease of the phosphatase activity by lowering the amount of free phosphate-would also favor glycogen storage by retarding glycogenolysis. We wish to call attention to the lowered alkaline phosphatase activity of the liver tissue in three cases of von Gierke's disease as compared to that of normal livers of two children. A subsequent report will deal with glycogenetic and phosphorylase-phosphatase glycogenolytic studies of tissue in von Gierke's disease, which are now in progress.

Values for total wet weight, total glycogen, total fat, and total nitrogen are not available in this series but may be studied in the future in order that the enzyme activity may be referred to the total parenchymal liver tissue.

\section{SUMMARY}

A report is made of the amylase and phosphatase activity of liver tissue in von Gierke's disease with a comparison of the activity of these enzymes in normal liver tissue and tissue of fatty livers.

The presence of amylolytic activity in von Gierke liver tissue is corroborated.

The alkaline phosphatase activity of the liver tissue in three cases of glycogen storage disease was found to be significantly lower than that present in normal livers of two children.

The authors wish to express their thanks to Dr. Kenneth D. Blackfan and Dr. Sidney Farber of the Children's Hospital in Boston and to Dr. Elmer Barron and Dr. Francis MacDonald of the Boston Floating Hospital for their cooperation in making the organs of the von Gierke patients available for our studies.' Much of the other material was obtained through the kindness of Dr. Timothy Leary.

\section{BIBLIOGRAPHY}

1. von Gierke, E., Hepato-Nephromegalia glykogenica. (Glykogenspeicherkrankheit der Leber und Nieren.) Beitr. z. path. Anat. u. z. allg. Path., 1929, 82, 497.

2. Schönheimer, R., Über eine eigenartige Störung des Kohlehydrat-Stoffwechsels. Ztschr. f. physiol. Chem., 1929, 182, 148.

3. Unshelm, E., Die Glykogenkrankheit (zugleich ein Beitrag zur Frage des hepatogenen Infantilismus). Jahrb. f. Kinderh., 1932, 137, 258.

4. Hertz, W., Fermentuntersuchungen Bei Glykogenspeicherkrankheit. Klin. Wchnschr., 1933, 12, 1725. 
5. Chrometzka, F., and Brumssen, H., Ferment-chemische Untersuchungen über die Glykogenspeicherkrankheit (von Gierke). Ztschr. f. klin. Med., 1939, 136, 122.

6. Cori, G. T., Cori, C. F., and Schmidt, G., The role of glucose-1-phosphate in the formation of blood sugar and synthesis of glycogen in the liver. J. Biol. Chem., 1939, 129, 629.

7. Ostern, P., Herbert, D., and Holmes, E., Formation and break-down of glycogen in the liver. Biochem. J., 1939, 33, 1858.

8. Thannhauser, S. J., and Setz, P., Studies on animal lipids. XII. A method for quantitative determina- tion of diaminophosphatide in organs and fluids. Application to stromata of red blood cells and serum. J. Biol. Chem., 1936, 116, 533.

9. Bodansky, A., Phosphatase studies. II. Determination of serum phosphatase. Factors influencing the accuracy of the determination. J. Biol. Chem., 1933, 101, 93.

10. Sorkin, S. Z. (To be published.)

11. Martland, M., and Robison, R., The possible significance of hexose-phosphoric esters in ossification. Part VII. The bone phosphatase. Biochem. J., 1927, 21, 665. 